\title{
Review
}

\section{Hyperthermia Chemo-sensitization, Chemical Thermo-sensitization and Apoptosis}

\author{
KANWAL AHMED ${ }^{1}$, TAKESHI HORI ${ }^{2}$, DA-YONG YU ${ }^{1}$, ZHENG-LI WEI ${ }^{1}$, \\ QING-LI ZHAO ${ }^{1}$, MASAO NAKASHIMA ${ }^{3}$, MARIAME ALI HASSAN ${ }^{1}$, \\ TAKASHI KONDO ${ }^{1 *}$
}

\author{
Department of ${ }^{1}$ Radiological Sciences, ${ }^{2}$ Orthopaedic Surgery, Graduate School of Medicine and Pharmaceutical \\ Sciences, University of Toyama, Toyama 930-0194, Japan \\ ${ }^{3}$ Department of Obstetrics and Gynecology, Toyama Prefectural Hospital, Toyama 930-8550, Japan
}

\begin{abstract}
Hyperthermia (HT) which can be directly cytotoxic to cancer cells, impairs the synthesis of cellular proteins : if not properly chaperoned by heat shock proteins (HSP), this can lead to irreversible and toxic protein aggregates. Clinically, it is preferred to use HT in combination with radiation therapy and chemotherapy. Although the combination of thermoradiotherapy has been widely studied, much attention has recently been focused on the search for compounds which can sensitize tumor cells to HT damage, but at the same time lead to minimal damage to normal cells. Synergy between HT and drugs may be caused by the occurrence of multiple events such as HT damage to ATP-binding cassette transporters, intracellular drug detoxification pathways, and the reparability of drug-induced DNA adducts. This may be why cells with acquired drug resistance (often multi-factorial) can be made responsive to drugs again by the combination of a drug exposure in conjunction with HT. In this review, the mechanism of HT-induced apoptosis and compounds which can sensitize cancer cells to HT-induced apoptosis are discussed.
\end{abstract}

Key Words: protein denaturation, protein aggregation, heat shock proteins, apoptosis

\section{Introduction}

Despite tremendous progress in chemotherapy and radiation therapy for the treatment of cancer, there is still a significant fraction of malignancies which is refractory to all current treatment modalities. The main obstacle facing conventional therapeutics is that the 'therapeutic window' between normal and tumor cells cannot be widened easily. An in-depth understanding of the molecular and cellular biology of cancer cells which has been made from revolutionary advances in the past two decades can now be utilized to help, provide excellent opportunities and strategies for novel therapeutic approaches. Hyperthermia has been recognized as an effective and attractive tool, especially in combination with conventional therapies, to halt tumor growth. The significant advantage of this type of combination

Received 20 November 2007, Accepted 12 February 2008. *Corresponding author; Tel, +81-76-434-7265; Fax, +81-76-434-5190;

e-mail, kondot@med.u-toyama.ac.jp

doi : $10.3191 /$ thermalmed.24.1

(C) 2008 Japanese Society for Thermal Medicine 
therapy is the possibility of using lower doses of chemotherapy or radiation, and thus potentially widening the current 'therapeutic windows', leading to more effective treatment with fewer unwanted side effects, and a reduced resistance of cancer cells to the combination of drugs and radiation.

There are many studies which deal with the biochemical and biophysical mechanisms leading to cell death from HT or from a combination of HT and ionizing radiation ${ }^{1-5)}$. In this report, mechanisms are reviewed which could be involved in the enhancement of apoptosis induced by a combination of HT and drugs.

\section{Effects of HT on cellular physiology}

Hyperthermia induces numerous changes in cellular physiology (Table I). These cellular alterations make a combination of heat and drugs very attractive. Below some important cellular responses to potential therapeutic regimens are discussed in detail.

Table I. Molecular effectors of hyperthermia

\begin{tabular}{|c|c|c|}
\hline Organelle & Functional changes & References \\
\hline Cell membrane & $\begin{array}{l}\text { Changes in fluidity/ stability } \\
\text { Alteration in structure } \\
\text { Impairment of ion transport }\left(\mathrm{Ca}^{2+}, \mathrm{Na}^{+}, \mathrm{Mg}^{+}, \mathrm{K}^{+}\right) \\
\text {Changes in membrane potential } \\
\text { Modulation of the transmembrane efflux pump }\end{array}$ & $(65)$ \\
\hline Cytoplasm & $\begin{array}{l}\text { Impairment of protein synthesis } \\
\text { Denaturation of protein structure and function } \\
\text { Aggregation of proteins } \\
\text { Induction of HSP synthesis }\end{array}$ & $(65)$ \\
\hline Mitochondria & $\begin{array}{l}\text { Increase permeability of mitochondrial inner membrane. } \\
\text { Depolarization of mitochondrial membrane potential } \\
\text { Depletion of ATP production } \\
\text { Production of reactive oxygen species (ROS) } \\
\text { Disruption of } \mathrm{Ca}^{2+} \text { transport across mitochondrial membrane. }\end{array}$ & $(67)$ \\
\hline $\begin{array}{l}\text { Endoplasmic } \\
\text { Reticulum (ER) }\end{array}$ & ER stress due to excessive accumulation of misfolded proteins. & $(68)$ \\
\hline Nucleus & $\begin{array}{l}\text { Impairment of RNA/DNA synthesis } \\
\text { Inhibition of DNA repair enzymes } \\
\text { Alteration of DNA conformation } \\
\text { Changes of gene expression and signal transduction }\end{array}$ & $(65)$ \\
\hline
\end{tabular}

\section{Changes in membrane permeability}

Membranes are known to be extremely sensitive to heat stress because of their complex molecular composition of lipids and proteins. At a certain temperature, lipids change from a tightly packed gel phase to a less tightly packed crystalline phase, and permeability of the cell membrane (membrane fluidity) increases. Hyperthermia-induced cell membrane permeability leads to increased drug delivery into tumor cells. In addition, increased vascular permeability due to thermal increases in endothelial gap size also aids drug delivery into tumors. Alteration in membrane permeability also alters the cellular content of several ions $\left(\mathrm{Na}^{+}, \mathrm{Mg}^{2+}, \mathrm{K}^{+}\right)$in a number of cells ${ }^{6)}$, although the changes in these ion 
balances are not primarily responsible for hyperthermic cell death ${ }^{7-9}$. Another ion which might be involved in hyperthermic cell death is $\mathrm{Ca}^{2+}$. Influxes of extracellular $\mathrm{Ca}^{2+}$ stimulates the activity of calmodulin-dependent protein kinases, inositol triphosphate production and other signaling cascades ${ }^{10}$.

\section{Alteration of cytoskeletal systems}

The response of cytoskeletal systems to HT varies depending on the cell type and HT dose ${ }^{11)}$. Hyperthermia-induced disassembly of the cytoskeleton enlarges the tumor pores which enables easier drug delivery ${ }^{11}$. It also induces alteration of the mitotic spindles ${ }^{11)}$, centrosome organization, and protein denaturation which results in the formation of multinucleated non-clonogenic cells ${ }^{12,13)}$.

\section{Inhibition of DNA repair}

DNA appears to be the primary target for most of the currently adopted chemotherapeutic drugs ${ }^{14}$. The main obstacle in chemotherapy is the resistance of cancer cells to the cytotoxic effects of these drugs. Several possible mechanisms have been suggested to account for this. Examples of these mechanisms include intrinsic DNA repair capabilities, reduced drug diffusion into areas of vascular insufficiency, and cellular impermeability ${ }^{15,16}$. Hyperthermia is reported to induce DNA double strand breaks due to the denaturation and dysfunction of heat-labile repair proteins such as DNA polymerases ${ }^{17)}$ or to the precipitation of denatured proteins onto nuclear chromatin structures, generating a barrier which prevents repair enzymes from reaching damage sites ${ }^{18}$. HT-induced protein denaturation is also reported to alter multiple nuclear matrix-dependent functions [e.g., DNA replication, DNA transcription, mRNA processing and DNA repair $]^{19}$.

It is thus hypothesized that hyperthermic treatment sensitizes tumor cells to other cancer treatments by altering cytoskeleton reorganization, enhancing membrane permeability and inhibiting DNA repair ${ }^{20)}$.

\section{HT-induced signal transduction}

\section{a) Apoptotic signal transduction}

Apoptosis is a genetically programmed and biochemically active mode of cell death in which the cell actively participates in its own destruction ${ }^{21)}$. It is required for cell life span regulation and normal development ${ }^{20)}$. Apoptosis also aids in the self-deletion of injured cells, terminal differentiation of epithelial cells, and organ and tissue shaping ${ }^{21)}$. Abnormalities in this process are implicated in several human diseases, including cancer. Radiation, cytotoxic drugs, viruses and hyperthermia can trigger this process.

Hyperthermia within a temperature range of $41-45^{\circ} \mathrm{C}$ induces apoptosis to varying degrees in many cell lines ${ }^{21}$. It induces apoptosis mainly through reactive oxygen species (ROS) generation, and a likely source of elevated ROS production is the mitochondria ${ }^{22)}$. Mitochondria are believed to produce basal levels of ROS in the form of single-electron leakage to oxygen during normal metabolism ${ }^{23}$. This can increase dramatically under conditions in which the mitochondria are damaged or exposed to certain toxic conditions ${ }^{22}$. In addition to this, HT can also alter the expression of the Bax and Bcl-2 genes, where such changes are dependent on the sensitivity of cell lines to $\mathrm{HT}^{24)}$. In thermo-resistant cell lines, HT by itself cannot change the expression of Bax and Bcl-2, but the combination of HT and 
chemotherapy or radiotherapy can up-regulate Bax and down-regulate Bcl-2 expression ${ }^{25)}$. Furthermore, hyperthermia-induced increases in intracellular $\mathrm{Ca}^{2+}$ ion $\left(\left[\mathrm{Ca}^{2+}\right] \mathrm{i}\right)$ concentration is also thought to be involved in cell death. However, evidence for the role of $\left[\mathrm{Ca}^{2+}\right] \mathrm{i}$ in hyperthermic cell death is contradictory. Some investigators have stated that HT-induced increases in $\mathrm{Ca}^{2+}$ do not play a key role ${ }^{26)}$, while others have concluded that thermal perturbations in $\left[\mathrm{Ca}^{2+}\right] \mathrm{i}$ are among the primary events leading to heat-induced cell killing ${ }^{27-29)}$. These observations suggest that the role of $\mathrm{Ca}^{2+}$ in $\mathrm{HT}$ induced cell killing may be dependent on cell type. HT is reported to increase the expression of IP3R $1^{30}$ which may regulate the release of $\mathrm{Ca}^{2+}$. Generally, $\mathrm{Ca}^{2+}$ can act on multiple targets to trigger apoptosis ${ }^{31)}$. Calpain, a calcium-dependent protease, has been considered as a possible target for calcium triggered apoptosis ${ }^{32)}$. Lipid peroxidation due to ROS generation is also reported to alter $\mathrm{Ca}^{2+}$ distribution ${ }^{33)}$ and to activate a $\mathrm{Ca}^{2+}$-dependent apoptotic pathway ${ }^{30)}$ (Fig. 1).

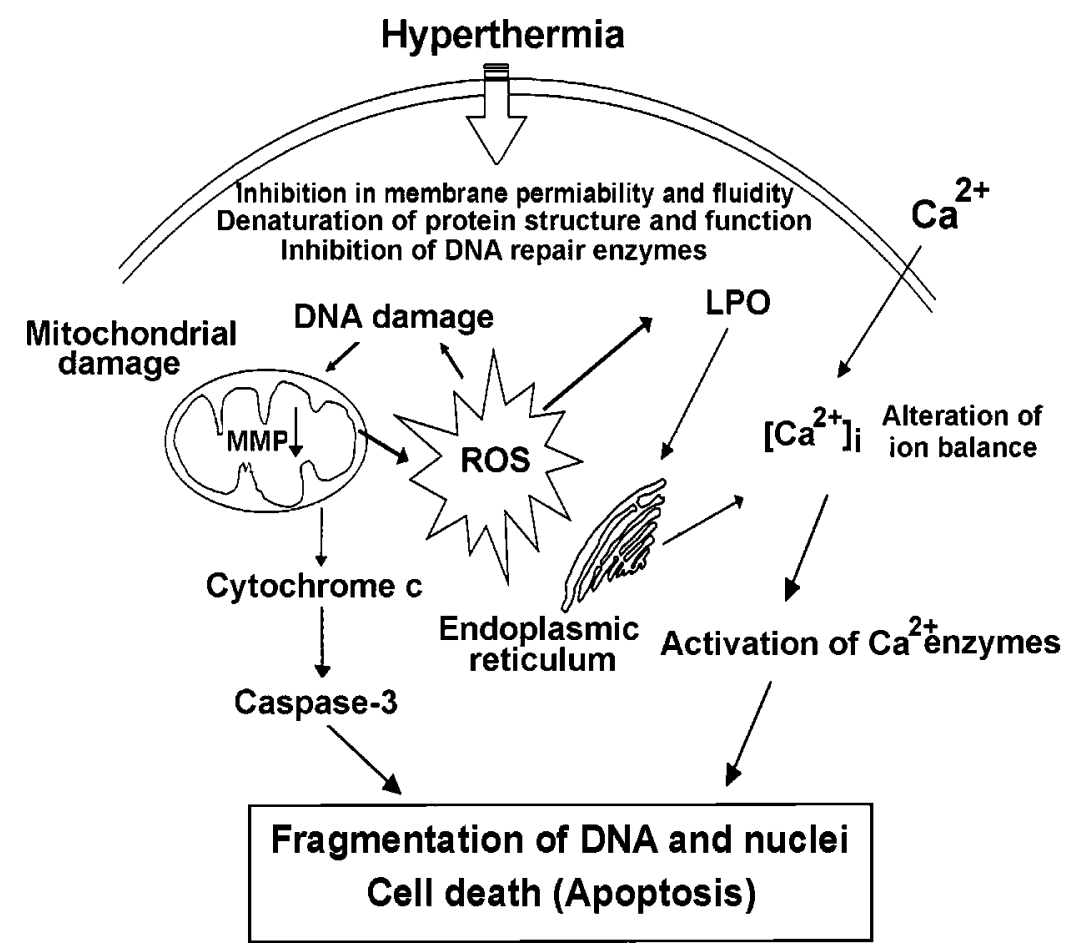

Fig. 1. Schematic summary of pathways involved in hyperthermic chemosensitization and chemical thermosensitization.

\section{b) Anti-apoptosis signal transduction :}

HT also simultaneously activates signal transduction pathways leading to anti-apoptosis activity and/or cellular proliferation. Key signaling factors, such as Akt, p38, extracellular signal-regulated kinase (ERK) and heat shock proteins (HSP) play important roles in anti-apoptosis or cellular proliferation pathways ${ }^{34}$. Such anti-apoptosis and cytoprotective signaling factors are known complications resulting from hyperthermia, and can lead to thermotolerance and chemoresistance. The presence of chemotherapeutic agents interferes with these pro-survival responses to hyperthermic monotherapy and can make cancer cells sensitive to HT. 
Thermo-sensitization in apoptosis $\cdot \mathrm{K}$. Ahmed et al.

\section{Enhancement of hyperthermia-induced apoptosis by traditional and newly synthesized chemical agents}

Hyperthermia alone plays no role in the curative treatment of human tumors ${ }^{35}$, therefore, much attention has been focused on combining HT with chemotherapy, and in searching for substances able to sensitize tumor cells to HT-induced damage ${ }^{36,37)}$. An ideal sensitizer would be nontoxic at normal temperatures, but would become toxic at hyperthermic temperatures. Below, chemical agents which can act as heat sensitizers at non-toxic concentrations are briefly discussed.

\section{a) Calcium channel blockers}

Calcium channel blockers, such as verapamil or diltiazem, have been commonly used to treat arrhythmia and angina pectoris. Verapamil also has other pharmacologic actions, such as reversing multiple drug resistance and suppressing metastasis of cancer cells in BALB/c mice injected with mouse mammary adenocarcinoma F3II cells ${ }^{38)}$. It also acts as a heat sensitizer in Chinese hamster ovary cells and U937 cells ${ }^{39)}$. It sensitizes both normal and thermo-tolerant U937 cells to HT-induced apoptosis by increasing $\left[\mathrm{Ca}^{2+}\right] \mathrm{i}$ concentration ${ }^{40)}$.

\section{b) Local anesthetics}

Local anesthetics (LAs) belong to a class of clinically useful compounds which exert their pharmacological effect by blocking nerve impulse propagation. There are many reports showing that HT induced cell death is modified by LAs (e.g. potentiation by procaine in murine L5178Y lymphoma cells ${ }^{41)}$, by lidocaine in murine FM3A mammary carcinoma cells ${ }^{42}$ and in murine tumor models ${ }^{43)}$, and by dibucaine, tetracaine, and procaine in hepatoma tissue culture cells ${ }^{44)}$ ). Investigations of the molecular mechanism of apoptosis enhancement by LAs at hyperthermic temperatures, have produced evidence that the elevation of $\left[\mathrm{Ca}^{2+}\right] \mathrm{i}$ is due to increased releases of $\mathrm{Ca}^{2+}$ from intracellular storage sites, and that this is caused by HT along with increased activity of the mitochondria caspase-dependent pathway (partly regulated by $\left[\mathrm{Ca}^{2+}\right] \mathrm{i}$ ), and that this plays a crucial role in the enhancement of apoptosis induced by the combination of HT and lidocaine ${ }^{45)}$.

\section{c) Temperature-dependent free radical generator}

A temperature-dependent free radical generator, 2,2'-azobis (2-amidinopropane) dihydrochloride (AAPH) acts as a heat sensitizer at non-toxic concentrations. It can sensitize hypoxic and thermo-tolerant cells, and enhances HT-induced apoptosis by increasing the $\left[\mathrm{Ca}^{2+}\right] \mathrm{i}$ concentration. Hyperthermia combined with exposure to AAPH led to a loss of mitochondrial membrane potential (MMP), indicating that mitochondria function was damaged by this treatment ${ }^{30}$. Furthermore, AAPH has been reported to inhibit HT-induced anti-apoptosis signaling factors ${ }^{46)}$.

\section{d) Intracellular $\mathrm{H}_{2} \mathrm{O}_{2}$ generator}

Another chemical agent which acts as a thermosensitizer is 6-formylpterin (6-FP). This compound generates intracellular $\mathrm{H}_{2} \mathrm{O}_{2}$ by transferring electrons from $\mathrm{NAD}(\mathrm{P}) \mathrm{H}$ to oxygen ${ }^{47)}$, and at nontoxic concentrations, it enhances HT-induced apoptosis. Some investigations suggest that the increase in the $\left[\mathrm{Ca}^{2+}\right]$ i concentration, the activation of mitochondria-caspase dependent pathways, and the translocation of PKC $\delta$ to mitochondria play important roles in 6-FP(8) enhancement of HT-induced apoptosis.

\section{e) Spin trap : $\alpha$-phenyl-tert-butyl nitrone}

Nitrone spin trap, $\alpha$-phenyl-tert-butyl nitrone (PBN) has been used, not only for electron 
paramagnetic resonance (EPR) -spin trapping studies, but also as an antioxidant in vitro and in vivo because PBN reacts with oxygen radicals to produce less reactive species ${ }^{49,50)}$. It has been reported that nitric oxide (NO) is released from PBN under oxidative stress conditions ${ }^{51,52)}$, and that HT induces oxidative stress in cells due to generation of superoxide $\left(\mathrm{O}_{2}^{-}\right)$. Consistent with these observations, it has been observed that PBN acts as a sensitizer for HT-induced apoptosis. When U937 cells were treated with a combination of HT and PBN, a significant enhancement of apoptosis was observed because NO reacts with $\mathrm{O}_{2}{ }^{-}$and produces $\mathrm{ONOO}^{-}$, and this $\mathrm{ROS}$ enhances $\mathrm{HT}$-induced apoptosis via stimulation of the mitochondria-caspase and the $\left[\mathrm{Ca}^{2+}\right] \mathrm{i}$-dependent pathways ${ }^{53)}$.

\section{f) Furan-fused tetracyclic compounds}

Recently, it was reported that a newly synthesized furan-fused tetracyclic compound, DF3 (a triisopropylsilyloxy (TIPS) derivative) acts as a heat sensitizer in U937 cells. DF3, at nontoxic concentrations with HT $\left(44^{\circ} \mathrm{C}\right.$ for $\left.20 \mathrm{~min}\right)$, showed a significant enhancement of heat-induced apoptosis. DF3 induced a sustained elevation of $\mathrm{O}_{2}{ }^{-}$and a transient rise of $\mathrm{H}_{2} \mathrm{O}_{2}$ generation, and there was a further increase in these compounds when DF3 exposure was combined with HT. This enhancement in oxidative stress appears to be the key event in the improved apoptotic response of U937 cells when subjected to a combination of DF3 and $\mathrm{HT}^{54}$.

\section{Mild hyperthermia enhances chemical agent induced apoptosis}

Hyperthermia produces synergistic results when combined with radiation or cytotoxic drugs at lower temperatures $\left(40.5-43^{\circ} \mathrm{C}\right.$ ) (Table II). However, it is beyond the scope of this short review to discuss all of the observed interactions between these drugs and HT separately. Below is a summary of reports describing some chemical agents which showed a synergistic enhancement of apoptosis when combined with mild HT.

\section{a) DNA-damaging agents}

HT can enhance the cytotoxicity of various DNA damaging agents. Most impressive is data for a combined HT and cisplatin treatment. Hyperthermia enhances intra-cellular platinum accumulation, reduces intra-cellular detoxification which leads to more platinum-induced DNA adducts, and inhibits repair of these adducts ${ }^{55}$. Interestingly, all of these processes are up-regulated in cells which have acquired platinum resistance ${ }^{55)}$. All of these enhancement effects appear to be due to HT-induced changes in cell metabolism, excretion, and membrane permeability or membrane transport ${ }^{56)}$. This has led to the suggestion that hyperthermia could be instrumental in reversing drug resistance, a major clinical problem in chemotherapy.

\section{b) Macrosphelides}

Recently, was reported that one of the synthetic diketone macrosphelides, specifically MS5 which is a 16-membered macrolide compound ${ }^{57)}$, led to the synergistic enhancement of apoptosis when combined with mild HT ( $41^{\circ} \mathrm{C}$ for $\left.20 \mathrm{~min}\right)$ in U937 lymphoma cells. Significant increases in reactive oxygen species (ROS) generation were observed immediately after the combined treatment. Combination of MS5 and mild HT also led to a MMP loss, indicating that mitochondrial dysfunction occurred during this treatment. Furthermore, Fas expression, caspase- 8 and caspase-3 activation were also observed at significantly increased levels after the combined treatment when compared with mild HT treatment alone. 
Table II. Heat-induced enhancement of drug cytotoxicity in apoptosis

\begin{tabular}{|c|c|c|c|c|c|}
\hline Drugs & $\begin{array}{l}\text { Target for } \\
\text { apoptosis }\end{array}$ & Cell line & Concentration $/{ }^{\circ} \mathrm{C}$ & $\begin{array}{l}\text { Maximum } \\
\text { Enhancement } \\
\text { Ratio }\end{array}$ & Ref \\
\hline $\begin{array}{c}\text { Cisplatin } \\
\text { (DNA damaging agent) }\end{array}$ & DNA & SW 1573 & $\begin{array}{c}5 \mu \mathrm{M} / 41-43^{\circ} \mathrm{C} \\
(60 \mathrm{~min})\end{array}$ & 7.3-7.8* & (69) \\
\hline $\begin{array}{c}\text { Lobaplatin } \\
\text { (DNA damaging agent) }\end{array}$ & DNA & SW 1573 & $\begin{array}{c}10 \mu \mathrm{M} / 41-43^{\circ} \mathrm{C} \\
(60 \mathrm{~min})\end{array}$ & $1.6-2.9^{*}$ & (69) \\
\hline $\begin{array}{c}\text { Oxaliplatin } \\
\text { (DNA damaging agent) }\end{array}$ & DNA & SW 1573 & $\underset{(60 \mathrm{~min})}{10 \mu \mathrm{M} / 41-43^{\circ} \mathrm{C}}$ & $2.0-2.1^{*}$ & (69) \\
\hline $\begin{array}{l}\text { Paclitexal } \\
\text { (Microtubule stabilizing agent) }\end{array}$ & Microtubules & FM3A & $\begin{array}{c}10 \mu \mathrm{M} / 43^{\circ} \mathrm{C} \\
(60 \mathrm{~min})\end{array}$ & $2.1^{*}$ & (70) \\
\hline $\begin{array}{l}\text { Etoposide (VP-16) } \\
\text { (DNA damaging agent) }\end{array}$ & DNA & LU65A & $\begin{array}{c}8 \mu \mathrm{M} / 43^{\circ} \mathrm{C} \\
(45 \mathrm{~min})\end{array}$ & $1.8^{*}$ & (71) \\
\hline $\begin{array}{l}\text { 5-Fluorouracil } \\
\text { (Anti-metabolite) }\end{array}$ & DNA and RNA & CCRF-CEM & $\begin{array}{c}100 \mu \mathrm{M} / 42^{\circ} \mathrm{C} \\
(120 \mathrm{~min})\end{array}$ & $1.0^{*}$ & (72) \\
\hline $\begin{array}{c}\text { Verapamil } \\
\left(\mathrm{Ca}^{2+} \text { Channel blocker }\right)\end{array}$ & Mitochondria & U937 & $\begin{array}{c}100 \mu \mathrm{M} / 42-44^{\circ} \mathrm{C} \\
(30 \mathrm{~min})\end{array}$ & $1.9-4.1^{\S}$ & (37) \\
\hline $\begin{array}{l}\text { Lidocaine } \\
\text { (Local anesthetic) }\end{array}$ & Mitochondria & U937 & $\underset{(10 \mathrm{~min})}{1 \mathrm{mM} / 44^{\circ} \mathrm{C}}$ & $3.6^{\S}$ & (44) \\
\hline $\begin{array}{c}\text { 2-Amidinopropane } \\
\text { dihydrochloride } \\
\text { (Temperature dependent free } \\
\text { radical generator) }\end{array}$ & Unknown & U937 & $\underset{(10 \mathrm{~min})}{50 \mathrm{mM} / 44^{\circ} \mathrm{C}}$ & $5.0^{\S}$ & (29) \\
\hline $\begin{array}{l}\text { 6-Formylpterin } \\
\text { (Intracellular hydrogen } \\
\text { peroxide generator) }\end{array}$ & Mitochondria & U937 & $\begin{array}{l}300 \mu \mathrm{M} / 44^{\circ} \mathrm{C} \\
(20 \mathrm{~min})\end{array}$ & $4.4^{\S}$ & (49) \\
\hline $\begin{array}{l}\alpha \text {-phenyl-tert-butyl nitrone } \\
\text { (Spin trap agent, antioxidant) }\end{array}$ & Unknown & U937 & $\begin{array}{l}10 \mathrm{mM} / 44^{\circ} \mathrm{C} \\
(10 \mathrm{~min})\end{array}$ & $5.7^{\S}$ & (54) \\
\hline $\begin{array}{c}\text { Furan-fused tetracyclic } \\
\text { compounds } \\
\text { (Anti-viral agent) }\end{array}$ & Mitochondria & U937 & $\begin{array}{c}20 \mu \mathrm{M} / 44^{\circ} \mathrm{C} \\
(20 \mathrm{~min})\end{array}$ & $6.6^{\S}$ & (55) \\
\hline $\begin{array}{c}\text { Macrosphelides } \\
\text { (Anti-metastatic agent) }\end{array}$ & Mitochondria & U937 & $\begin{array}{c}5 \mu \mathrm{M} / 41^{\circ} \mathrm{C} \\
(20 \mathrm{~min})\end{array}$ & $2.1^{\S}$ & (57) \\
\hline $\begin{array}{c}\text { Anisomycin } \\
\text { (Protein synthesis inhibitor) }\end{array}$ & Proteins & U937 & $\begin{array}{l}0.1 \mathrm{mM} / 41^{\circ} \mathrm{C} \\
(60 \mathrm{~min})\end{array}$ & $1.5^{\S}$ & $\#$ \\
\hline $\begin{array}{l}\text { 6-Dimethyl-a minopurine } \\
\text { (Protein kinase inhibitor) }\end{array}$ & Unknown & U937 & $\begin{array}{c}2 \mathrm{mM} / 41^{\circ} \mathrm{C} \\
(60 \mathrm{~min})\end{array}$ & $1.5^{\S}$ & $\#$ \\
\hline
\end{tabular}

* Maximum enhancement ratio=Cell death (\%) (measured with different methods) in the presence of the drug at elevated temperature/Cell death $(\%)$ in the presence of drug at a normal temperature $\left(37^{\circ} \mathrm{C}\right)$.

$\S$ Maximum enhancement ratio $=$ DNA fragmentation (\%) in the presence of a drug at elevated temperatures/DNA fragmentation

$(\%)$ in the presence of a drug at a normal temperature $\left(37^{\circ} \mathrm{C}\right)$.

\# Unpublished data. 
Moreover, this combined treatment also altered the expression of apoptosis-related proteins, which was shown by the cleavage of Bid and the down-regulation of Bcl-2. The results have indicated that an early increase in ROS generation was primarily responsible for the synergistic enhancement of apoptosis after a combined treatment ${ }^{58)}$.

\section{c) Anisomycin}

The effects of HT in combination with antibiotics were reported previously ${ }^{43)}$. Some antibiotics such as Bleomycin, Doxorubicin and Actinomycin D showed more than an additive cell killing when combined with $\mathrm{HT}^{35}$.

Recently, the effect of a combination of mild HT $\left(41^{\circ} \mathrm{C}\right.$ for $\left.60 \mathrm{~min}\right)$ and anisomycin was examined in U937 cells. This antibiotic is a reversible inhibitor of protein biosynthesis and also has been reported to inhibit DNA synthesis ${ }^{59)}$. It also induces strong activation of JNK and P38 mitogen-activated protein kinase $^{60)}$. In preliminary studies, a significant synergistic enhancement of apoptosis was observed after a combined treatment when compared to anisomycin alone $(27.2 \pm 3.0 \%$ and $17.8 \pm 4.1 \%$. respectively). Mitochondrial dyfunction was also observed during this treatment indicating the involvement of mitochondrial apoptosis pathways.

\section{d) 6-Dimethylaminopurine}

Many alkylating agents, such as Melphalan, Ifosfamide and Mitomycin $\mathrm{C}^{35}$ ) have been reported to show additive cell killing when combined with HT. The alkylpurine, 6-dimethylaminopurine (6-DMAP) is a protein kinase inhibitor known to induce premature mitosis in S-phase arrested hamster cells ${ }^{61,62)}$, and has been reported to induce apoptosis in HeLa cells ${ }^{63)}$ and in epidermal growth factor and insulin treated $\mathrm{G}_{0}$-phase Chinese hamster embryonic fibroblast $(\mathrm{CHEF} / 18)$ cells ${ }^{64)}$. The effects of 6-DMAP in combination with mild HT $\left(41^{\circ} \mathrm{C}\right.$ for $\left.60 \mathrm{~min}\right)$ were examined in U937 cells. Preliminary data showed a synergistic enhancement of DNA fragmentation in cells treated with the combination when compared to 6-DMAP and mild HT alone $(43.4 \pm 8.2 \%, 28.6 \pm 6.2 \%$ and $8.4 \pm 0.4 \%$ respectively). However, further studies with anisomycin and 6-DMAP in combination with HT are still necessary to propose any detailed mechanism which can explain how these agents may be involved with apoptosis.

\section{Conclusion}

HT sensitizes cells to many cytotoxic agents, and even converts some innocuous drugs into highly toxic agents. HT alters the pharmacokinetics and pharmacodynamics of drugs ${ }^{65)}$, increases DNA damage $^{15)}$, decreases DNA repair ${ }^{8,12)}$ and alters membrane permeability ${ }^{65)}$. Furthermore, HT can also lead to the modulation of cellular ROS concentrations, which could be responsible for thermal chemo-sensitization in cancer therapy. These HT-induced cellular changes may also have the potential to overcome some types of drug resistance ${ }^{66)}$. Further detailed studies with combinations of drugs and HT are still required to identify effective heat sensitizers for cancer therapy.

\section{Acknowledgement}

This work was supported in part by a Grant-in-Aid from Japanese Ministry of Education, Culture, Sports, Science, and Technology. 


\section{References}

1) Lepock J.R. : Role of nuclear protein denaturation and aggregation in thermal radiosensitization. Int J Hyperthermia, $20: 115-130,2004$.

2) Kampinga H.H., Dikomey E. : Hyperthermic radiosensitization : mode of action and clinical relevance. Int J Radiat Biol, 77 : 399-408, 2001.

3) Kampinga H.H., Dynlacht J.R., Dikomey E. : Mechanism of radiosensitization by hyperthermia $\left(\geq 43^{\circ} \mathrm{C}\right)$ as derived from studies with DNA repair defective mutant cell lines. Int J Hyperthermia, 20: 131-139, 2004.

4) Sellins K.S., Cohen J.J. : Hyperthermia induces apoptosis in thymocytes. Radiat Res, 126: 88-95, 1991.

5) Yonezawa M., Otsuka T., Matsui N., Tsuji H., Kato K.H., Moriyama A., Kato T. : Hyperthermia induces apoptosis in malignant fibrous histiocytoma cells in vitro. Int J Cancer, 66 : 347-351, 1996.

6) Chu G.L., Dewey W.C. : Effect of hyperthermia on intracellular pH in Chinese hamster ovary cells. Radiat Res, 110 : 439-449, 1987.

7) Vider C.A., Dewey W.C. : Evaluation of a role for intracellular $\mathrm{Na}^{+}, \mathrm{K}^{+}, \mathrm{Ca}^{2+}$ and $\mathrm{Mg}^{2+}$ in hyperthermic cell killing. Radiat Res, 105, 187-200, 1986.

8) Ruifork A.C.C., Kanon B., Konings A.W.T. : Heat induced $\mathrm{K}^{2+}$ loss, trypan blue uptake and cell lysis in different cell lines: effect of serum. Radiat Res, 109: 303-309, 1987.

9) Cook J.A., Fox M.H. : Intracellular $\mathrm{pH}$ of Chinese hamster ovary cells heated at $45^{\circ} \mathrm{C}$ at $\mathrm{pH}$ 6.6. Radiat Res, 115 : 421-435, 1988.

10) Cividalli A., Cruciani G., Livdi E., Pasqualetti P., Danesi D.: Hyperthermia enhances the response of paclitaxel and radiation in a mouse adenocarcinoma. Int J Radiat Oncol Biol Phys, 44 : 407-412, 1999.

11) Huang S., Yang K., Wu J., Chang K., Wang S. : Effects of hyperthermia on the cytoskeleton and focal adhesion proteins in a human thyroid carcinoma cell line. J Cell Biochem, 75 : 327-337, 1999.

12) Vidair C.A., Doxsey S.J., Dewey W.C. : Heat shock alters centrosome organizationleading to mitotic dysfunction and cell death. J Cell Physiol, 154 : 435-455, 1993.

13) Nakahata K., Miyakoda M., Suzuki K., Kodama S., Watanabe M. : Heat shock induces centrosomal dysfunction and causes non-apoptotic mitotic catastrophe in human tumor cells. Int J Hyperthermia, 18 : 332-343, 2002.

14) Kohn K.W. : DNA as a target in cancer chemotherapy: Measurement of macromolecular DNA damage produced in mammalian cells by anticancer agents and carcinogens. Methods Cancer Res, 16: 291-345, 1979.

15) DeVita Jr. V.T. : Principles of chemotherapy. "Cancer Principles and Practice of Oncology, Second Edition" Eds. V.T. DeVita, S. Hellman, S.A. Rosenberg, Lippincott, pp257-286, 1985.

16) Andrews P.A., Velury S., Mann S.C., Howell S.B. : cis-Diamminedichloroplatinum (II) accumulation in sensitive and resistant human ovarian carcinoma cells. Cancer Res, 48 : 68-73, 1988.

17) Takahashi A., Matsumoto H., Kosuke N., Kitano M., Hirose S., Tanaka H., Mori E., Yamakawa N., Yasumoto J., Yuki K., Ohnishi K., Ohnishi T. : Evidence for the involvement of double-strand breaks in heat-induced cell killing. Cancer Res, $64:$ 8839-8854, 2004.

18) Wachsberger P.R., Iliakis G. : Hyperthermia does not affect rejoining of DNA double-strand breaks in a cell free assay. Int J Radiat Biol, 76 : 313-326, 2000.

19) Tentori L., Orlando L., Lacal M.P., Benincasa E., Faraoni I., Bonmassar E., D’Atri S., Graziani G.: Inhibition of $\mathrm{O}^{6}$-alkylguanine DNA-alkyltransferase or poly (ADP-ribose) polymerase increases susceptibility of leukemic cells to apoptosis induced by temozolomide. Mol Pharmacol, 52 : 249-258, 1997.

20) Luchetti F., Mannello F., Canonico B., Battistelli M., Burattini S., Falcieri E., Papa S. : Integrin and cytoskeleton behaviour in human neuroblastoma cells during hyperthermia-related apoptosis. Apoptosis, 9: 635-648, 2004.

21) Poe B., O’Neill K. : Inhibition of protein synthesis sensitizes thermotolerant cells to heat shock-induced apoptosis. 
Apoptosis, 2 : 510-517, 1997.

22) Zuo L., Christofi F.L., Wright P.V., Liu C.Y., Merola A.J., Berliner L.J., Clanton T.L.: Intra and extracellular measurement of reactive oxygen species produced during heat stress in diaphragm muscle. Am J Physiol Cell Physiol, 279: C1058-C1066, 2000

23) Chance B., Sies H., Boveris A.: Hydroperoxide metabolism in mammalian organs. Physiol Rev, 59 : 527-605, 1979.

24) Basile A., Biziato D., Sherbet V.G., Comi P., Cajone F.: Hyperthermia inhibits cell proliferation and induces apoptosis : relative signaling status of P53, S100A4, and notch in heat sensitive and resistant cell lines. J Cell Biol, 103 : 212-220, 2008.

25) Liang H., Zhan J.H., Wang B.G., Pan Y., Hao S. X: change in expression of apoptosis genes after hyperthermia, chemotherapy and radiotherapy in human colon cancer transplanted into nude mice. World J Gastroentrol, 13: 4365-4371, 2007.

26) Vidair C.A., Wang Z., Dewey W.C. : Non-involvement of heat-induced increase in intracellular free $\mathrm{Ca}^{2+}$ concentration for thermal killing and induction of thermotolerance. Radiat Res, 124: 156-164, 1990.

27) Stevenson M.A., Calderwood L.K., Hahn G.M. : Rapid increase in inositol and intracellular $\mathrm{Ca}^{2+}$ after heat shock. Biochem Biophys Res Commun, 137 : 826-833, 1986.

28) Mikkelsen R.B., Reinlib L., Donowitz M., Zahniser D. : Hyperthermia effects on cytosolic [Ca ${ }^{2+}$. Analysis at single cell level by digitized imaging microscopy and cell survival. Cancer Res, $51: 359-364,1991$.

29) Drummond I.A.S., Livingstone D., Steinhardt R.A.: Heat shock protein synthesis and cytoskeletal rearrangements occur independently of intracellular free calcium increases in Dorsophila cells and tissues. Radiat Res, 113: 402-413, 1988.

30) Li F.J., Kondo T., Zhao Q.L., Tanabe K., Ogawa R., Li M., Arai Y. : Enhancement of hyperthermia-induced apoptosis by a free radical initiator, 2,2'-azobis (2-amidinopropane) dihydrochloride, in human histiocytic lymphoma U937 cells. Free Radiat Res, 35 : 281-299, 2001.

31) Nunez G., Benedict M.A., Hu Y., Inohara N.: Caspases: the proteases of the apoptotic pathway. Oncogene, 17 : 3237-3245, 1998.

32) Carafoli E., Molinari M. : Calpain a protease in search of a function. Biochem Biophys Res Commun, 247: 193-203, 1998.

33) Fabisiak J.P., Tyurina Y.Y., Tyurin V.A., Lazo J.S., Kagan V.E. : Random versus selective membrane phospholipid oxidation in apoptosis: Role of phosphatidylserine, Biochemistry, 37: 13781-13790, 1998.

34) Ohnishi K., Ohnishi T. : Hyperthermic sensitizers targeting heat-induced signal transduction. Ann Cancer Res Therap, $15: 35-40,2007$.

35) Overgaard J.: Rationale and problems in the design of clinical trials. "Volume 2 Hyperthermic Oncology" Ed. J. Overgaard, Taylor and Francis, pp325-338, 1985.

36) Tiecher B.A., Abrams M.J., Rosbe K.W., Herman T.S.: Cytotoxicity, radiosensitization, antitumor activity and interaction with hyperthermia of a Co (III) mustard complex. Cancer Res, 50: 6771-6975, 1990.

37) Overgaard J., Radacic M.M., Garu C.: Interaction of hyperthermia and cis-diammine-dichloroplatinum alone or combined with radiation in a C3H mammary carcinoma in vivo. Cancer Res, 51: 707-711, 1991.

38) Farias E.F., Ghiso A.A.J., Ladeda V., Joffe E.B. : Verapamil inhibits tumor protease production, local invasion and metastasis development in murine carcinoma cells. Int J Cancer, 78: 727-734, 1998.

39) Coss R.A., Felgar R.E., Stokes D.G., Smith N.N. : Effect of verapamil and diltiazem on hyperthermic cell death in CHO cells. Int J Hyperthermia, 5 : 383-387, 1989.

40) Kameda K., Kondo T., Tanabe K., Zhao Q.L., Seto H.: The role of intracellular $\mathrm{Ca}^{2+}$ in apoptosis induced by hyperthermia and its enhancement by verapamil in U937 cells. Int J Radiat Oncol Biol Phys, 49 : 1369-1379, 2001.

41) Yau T.M. : Procaine-mediated modification of membranes and of the response to X-irradiation and hyperthermia in 
mammalian cells. Radiat Res, 80 : 523-541, 1979.

42) Mizuno S., Ishida A. : Selective enhancement of the cytotoxicity of the bleomycin derivative, peplomycin, by local anesthetics alone and combined with hyperthermia. Cancer Res, 42: 4726-4729, 1982.

43) Robins H.I., Dennis W.H., Slattery J.S., Lange T.A., Yatvin M.B.: Systemic lidocaine enhancement of hyperthermia-induced tumor regression in transplantable murine tumor models. Cancer Res, 43: 3187-3191, 1983.

44) Kingston C.A., Ladha S., Manning R., Bowler K. : The effect of local anesthetics on the thermal sensitivity of HTC cells. Anticancer Res, 13 : 2235-2240, 1993.

45) Arai Y., Kondo T., Tanabe K., Zhao Q.L., Li F.J., Ogawa R., Li M., Kasuya M.: Enhancement of hyperthermia-induced apoptosis by local anesthetics on human histiocytic lymphoma U937 cells. J Biol Chem, 277 : 18986-18993, 2002.

46) Wang C.C., Chen F., Kim E., Harrison L.E. : Thermal sensitization through ROS modulation : a strategy to improve the efficacy of hyperthermic intraperitoneal chemotherapy. Surgery, 142: 384-392, 2007.

47) Arai T., Endo N., Yamashita K., Sasada M., Mori H., Ishii H., Hirota K., Makino K., Fukuda K. : 6-formylpterin, a xanthine oxidase inhibitor, intracellularly generates reactive oxygen species involved in apoptosis and cell proliferation. Free Radic Biol Med, 30 : 248-259, 2001.

48) Wada S., Cui Z.G., Kondo T., Zhao Q.L., Ogawa R., Shoji M., Arai T., Makino K., Furuta I.: A hydrogen peroxide-generating agent, 6-formylpterin, enhances heat-induced apoptosis. Int J Hyperthermia, 21 : 231-246, 2005.

49) Floyd R.A. : Antioxidants, oxidative stress, and degenerative neurological disorders. Proc Soc Exp Biol Med, 222 : 236-245, 1999.

50) Kotake Y.: Pharmacologic properties of $\alpha$-phenyl N-tert butylnitrone. Antioxid Redox Signal, 1: 481-499, 1999.

51) Saito K., Yoshioka H., Kazama S., Cutler R.G. : Release of nitric oxide from a spin trap, N-tert-butyl- $\alpha$-phenylnitrone, under various oxidative conditions. Biol Pharm Bull, 21 : 401-404, 1998.

52) Saito K., Yoshioka H. : ESR characterization of a novel spin trapping agent, ${ }^{15} \mathrm{~N}$-labeled N-tert-butyl- $\alpha$-phenylnitrone, as a nitric oxide donor. Biosci Biotechnol Biochem, 66:2189-2193, 2002.

53) Cui Z.G., Kondo T., Matsumoto H.: Enhancement of apoptosis by nitric oxide released from $\alpha$-phenyl-tert-butyl nitrone under hyperthermic conditions. J Cell Physiol, 206: 468-476, 2006.

54) Yu D.Y., Matsuya Y., Zhao Q.L., Ahmed K., Wei Z.L., Nemoto H., Kondo T. : Enhancement of hyperthermia-induced apoptosis by a new synthesized class of furan-fused tetracyclic compounds. Apoptosis, 12: 1523-1532, 2007.

55) Andrews P.A., Velury S., Mann S.C., Howell S.B. : cis-Diamminedichloroplatinum (II) accumulation in sensitive and resistant human ovarian carcinoma cells. Cancer Res, 48: 68-73, 1988.

56) Dahl O.: Interaction of heat and drugs in vitro and in vivo. "Thermoradiotherapy and Thermochemotherapy. Vol.1, Biology, Physiology and Physics” Eds. M.H. Seegenschmiedt, P. Fessenden, CC. Vernon, Springer-Verlag, pp623-636, 1995.

57) Ishihara K., Kawaguchi T., Matsuya Y., Sakurai H., Saiki I., Nemoto H. : Synthesis and biological evaluation of macrosphelide cores. Eur J Org Chem, 19: 3973-3978, 2004.

58) Ahmed K., Zhao Q.L., Matsuya Y., Yu D.Y., Salunga T.L., Nemoto H., Kondo T.: Enhancement of macrosphelide-induced apoptosis by mild hyperthermia. Int J Hyperthermia, 23 : 353-361, 2007.

59) Grollman A. : Inhibitors of protein biosynthesis : Mode of action of anisomycin. J Biol Chem, 242 : 3226-3233, 1967.

60) Cano E., Mahadevan L.C.: Parallel signal processing among mammalian MAPKs. Trends Biochem Sci, 20 : 117-122, 1995.

61) Schlegel R., Belinsky G.S., Harris M.O. : Premature mitosis induced in mammalian cells by the protein kinase inhibitors 2-aminopurine and 6-dimethylaminopurine. Cell Growth Differ, 1: 171-178, 1990.

62) Steinmann E.K., Belinsky G.S., Lee D., Schlegel R. : Chemically induced premature mitosis : Differential response in rodent and human cells and the relationship to cyclin B synthesis and p34 cdc2/cyclin B complex formation. Proc Natl 
Acad Sci USA, 88 : 6843-6847, 1991

63) Meikrantz W., Gisselbrecht S., Tam S.W., Schiegel R. : Activation of cyclin A-dependent protein kinases during apoptosis. Proc Natl Acad Sci USA, 91 : 3754-3758, 1994.

64) Bonatti S., Pigullo S., Simili M., Abbondandolo A. : Induction of apoptosis and inhibition of signaling pathways by alkylated purines. Mutagenesis, 15: 361-366, 2000.

65) Hilderandt B., Wust P., Ahlers O., Dieing A., Sreenivasa G., Kerner T., Felix R., Riess H. : The cellular and molecular basis of hyperthermia. Crit Rev Oncol Hematol, 43 : 33-56, 2002.

66) Kowal C.D., Bertino JR. : Possible benefits of hyperthermia to chemotherapy. Cancer Res, 39 : $2285-2289,1979$.

67) White M.G., Luca E.L., Nonner D., Saleh O., Hu B., Barrett E.F., Barrett J.N : Cellular mechanisms of neuronal damage from hyperthermia. Prog Brain Res, 61: 347-371, 2007.

68) Meares P.G., Zmijewska A.A., Jope R.S. : HSP105 interacts with GRP78 and GSK 3 and promotes ER stress-induced caspase-3 activation. Cell Signal, $20: 347-358,2008$.

69) Rietbroek R.C., van de Vaart P.J.M., Haveman J., Blommaert F.A., Geerdink A., Bakker P.J., Veenhof C.H.: Hyperthermia enhances the cytotoxicity and platinum-DNA adduct formation of laboplatin and oxaliplatin in cultured SW 1537 cells. J Cancer Res Clin Oncol, 123 : 6-12, 1997.

70) Othman T., Goto S., Lee J.B., Taimura A., Matsumoto T., Kosaka M. : Hyperthermic enhancement of the apoptotic and antiproliferative activities of Paclitexal. Pharmacology, 62 : 208-212, 2001.

71) Nakao K., Otsuki Y., Akao Y., Ito Y., Marukawa O., Tachibana S., Kawakami M., Sasaki S. : The synergistic effects of hyperthermia and anticancer drugs on induction of apoptosis. Med Electron Microsc, 33: 44-50, 2000.

72) Mini E., Dombrowski J., Moroson A.B., Bertino R.J.: Cytotoxic effects of hyperthermia, 5-florouricil and their combination on a human leukemia T-lymphoblast cell line, CCRF-CEM. Eur J Cancer Clin Oncol, 22 : 927-934, 1986. 